
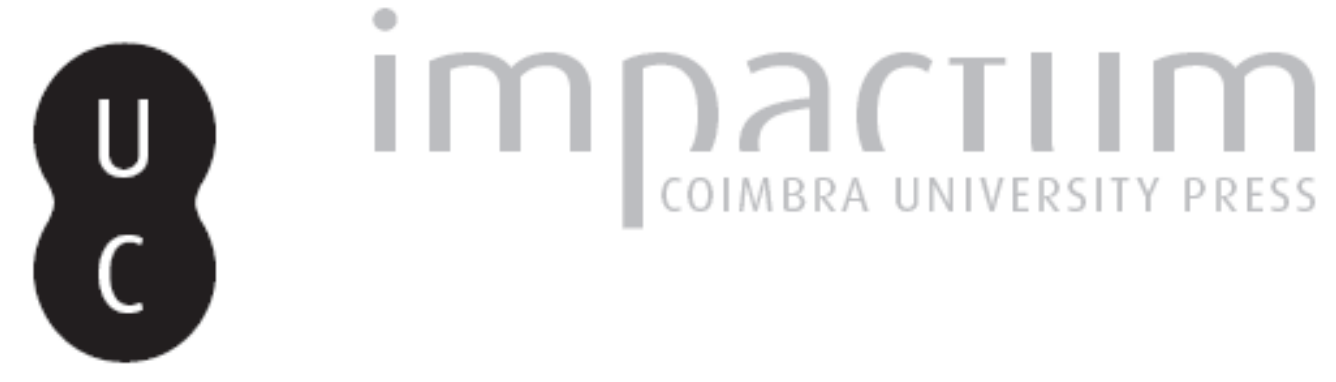

\title{
A integração regional nos discursos de FHC e Lula: um estudo comparativo
}

Autor(es): $\quad$ Wenzel, Fernanda; Haffner, Jacqueline A.

Publicado por: Imprensa da Universidade de Coimbra

URL persistente:

URI:http://hdl.handle.net/10316.2/41333

DOI:

DOI:https://doi.org/10.14195/1647-6336_16_6

Accessed : $\quad$ 26-Apr-2023 15:46:06

A navegação consulta e descarregamento dos títulos inseridos nas Bibliotecas Digitais UC Digitalis, UC Pombalina e UC Impactum, pressupõem a aceitação plena e sem reservas dos Termos e Condições de Uso destas Bibliotecas Digitais, disponíveis em https://digitalis.uc.pt/pt-pt/termos.

Conforme exposto nos referidos Termos e Condições de Uso, o descarregamento de títulos de acesso restrito requer uma licença válida de autorização devendo o utilizador aceder ao(s) documento(s) a partir de um endereço de IP da instituição detentora da supramencionada licença.

Ao utilizador é apenas permitido o descarregamento para uso pessoal, pelo que o emprego do(s) título(s) descarregado(s) para outro fim, designadamente comercial, carece de autorização do respetivo autor ou editor da obra.

Na medida em que todas as obras da UC Digitalis se encontram protegidas pelo Código do Direito de Autor e Direitos Conexos e demais legislação aplicável, toda a cópia, parcial ou total, deste documento, nos casos em que é legalmente admitida, deverá conter ou fazer-se acompanhar por este aviso.

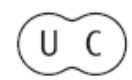


DEBATER

A EUROPA

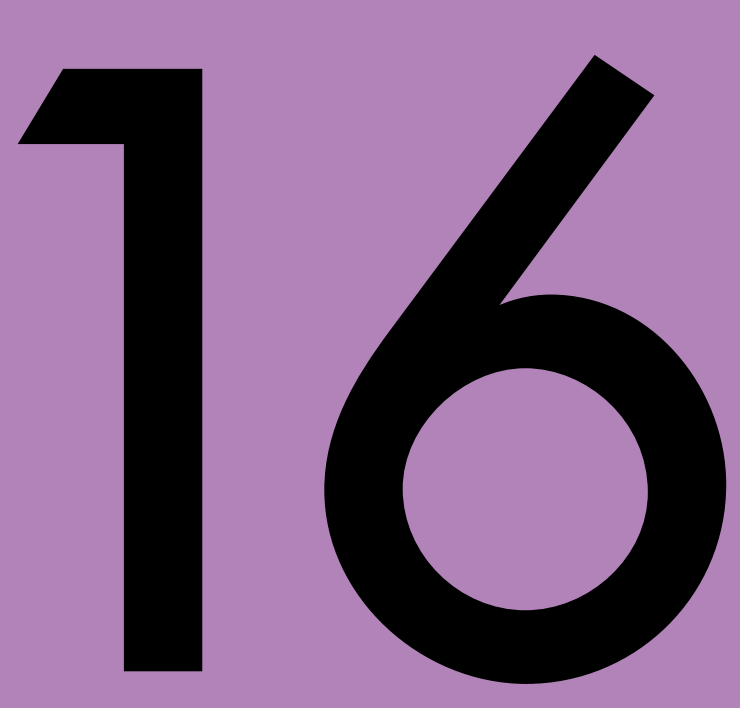

jan-jun 2017

FENÓMENOS DE INTEGRAÇÃO

REGIONAL: OS CASOS DA UNIĨO

EUROPEIA E O MERCOSUL

PHENOMENA OF REGIONAL INTEGRATION: THE

CASES OF THE EUROPEAN UNION AND MERCOSUR 


\section{A integração regional nos discursos de FHC e Lula: um estudo comparativo Regional integration in the discourses of FHC and Lula:
a comparative study}

Fernanda Wenzel Mestre em Estudos Estratégicos Internacionais pela UFRGS, Brasil

E-mail: nandawenzel@yahoo.com.br

Jacqueline A. Haffner, PhD Coordenadora do Curso de Relações Internacionais Departamento de Economia e Relações Internacionais - UFRGS, Brasil E-mail: jacqueline.haffner@ufrgs.br

\section{Resumo}

Tanto o governo Fernando Henrique como o governo Lula tiveram a integração regional como prioridade de sua política externa. Sabe-se, no entanto, que cada presidente assumiu o poder em contextos internacionais bastante específicos, além de terem posturas diferentes em relação ao sistema internacional. Através da análise dos discursos de cada mandatário nas reuniões de Cúpula das Américas, será possível identificar as diferenças entre as políticas externas dos dois governos na busca do mesmo objetivo: a integração regional.

Palavras-chave: FHC; Lula, integração regional; política externa brasileira; Mercosul

\section{Abstract}

The regional integration was a priority both to President Fernando Henrique as to President Lula. Nevertheless, it is known that each president came to power in very specific international contexts. Moreover, FHC and Lula have had different attitudes towards the international system. Through the analyses of the speeches of each president in the Summits of Americas, it will be possible to identify the diferences between this two governments in search of the same objective: the regional integration.

Keywords: FHC; Lula; regional integration; brasilian foreign policy; Mercosul 


\section{Introdução}

A valorização do entorno regional é apontada como a principal linha de continuidade entre a política externa dos governos Fernando Henrique Cardoso (1995-2002) e Luiz Inácio Lula da Silva (2003-2010). A contribuição de Cardoso para o processo de integração regional começou quando ele ainda era Ministro das Relações Exteriores do governo Itamar Franco, presidente que tornou o Mercosul a prioridade da agenda internacional brasileira. Ao assumir a presidência da república, Cardoso dá continuidade a este processo, e defende a manutenção do Mercosul em duas situações delicadas para o bloco: as negociações em torno do projeto da Área de Livre Comércio das Américas (ALCA) e a crise regional desencadeada pela desvalorização do real em 1999. Ao assumir a presidência em 2003, Lula aprofundaria este processo, com destaque para a criação da Unasul e do Conselho de Defesa Sul-Americano

Apesar da constatação de que ambos presidentes priorizavam o entorno regional, não se pode ignorar as diferenças entre as políticas de cada governo para este mesmo entorno - seja em função dos diferentes contextos históricos ou das diferentes estratégias adotadas. O objetivo deste trabalho é justamente identificar e analisar as diferenças e semelhanças entre as políticas dos governos FHC e Lula em relação aos processos de integração do continente americano e ao modo como o Brasil se relaciona com os países vizinhos.

Isto será feito a partir da análise dos discursos dos presidentes FHC e Lula nas Reuniões de Cúpula das Américas, já que se entende que este é um momento chave no qual os líderes dos países expõem suas posições acerca das questões regionais. A primeira reunião aconteceu em 1994, em Miami, onde foi apresentado o projeto da Alca. A partir de então, as cúpulas vêm sendo realizadas a cada três ou quatro anos. Segundo a página da Organização dos Estados Americanos na internet, os líderes do hemisfério ocidental se reúnem periodicamente para discutir problemas comuns, buscar soluções e desenvolver uma visão compartilhada para o desenvolvimento da região, seja ela social, econômica, ou de natureza política (ORGANIZAÇÃO DOS ESTADOS AMERICANOS, 2016).

A revisão bibliográfica demonstra que muitas pesquisas já foram feitas no sentido de ampliar o entendimento acerca dos projetos de integração regional desenvolvidos pelos governos FHC e Lula, seja analisando-os separadamente ou em termos comparativos. Estes estudos avançam sobre variadas temáticas, como a questão da identidade sul-americana, da institucionalização dos projetos de integração e dos aspectos políticos e econômicos que influenciaram estes processos.

Santos (2014) analisa as mudanças na identidade brasileira desde os tempos do Império, com foco na construção de uma identidade sul-americana. A análise de discurso é utilizada em sua pesquisa, porém a título ilustrativo, e não como objeto de análise. Meunier e Medeiros 
(2013) também se voltam para a questão da identidade, e para isso analisam os discursos proferidos por chefes de Estado e ministros das Relações Exteriores nas reuniões da Unasul e também nos encontros que precederam a criação desta instituição. Sua hipótese de pesquisa é de que os líderes políticos buscaram, através dos discursos, promover uma identificação social no processo de constituição da Unasul. Já Leandro de Freitas Couto (2010) defende a hipótese de que a partir do governo Lula foi intensificado o processo de institucionalização das relações multilaterais do Brasil para a América do Sul. Para isso se utiliza de alguns trechos de discursos de Lula e de seu chanceler, também a título ilustrativo. Saraiva (2010), por sua vez, delimita sua pesquisa ao governo Lula, e afirma que o presidente se diferenciou de seus antecessores ao buscar a liderança brasileira na América do Sul. Martins, em sua pesquisa, utilizou discursos presidenciais e diplomáticos para analisar os propósitos político e estratégico que nortearam a política de integração regional do governo FHC.

Apesar da clara contribuição para o campo de pesquisa, nenhum destes trabalhos traz uma análise mais ampla dos projetos de integração regional de Cardoso e Lula, e do modo como cada presidente expressava e defendia seu respectivo projeto. Mais do que isso, não revelam qual a mensagem que cada presidente transmitia ao restante do continente americano, seja em relação ao posicionamento diante das grandes potências (em especial os EUA), como também a uma eventual liderança regional do Brasil.

A partir destes questionamentos e da análise dos discursos dos presidentes nas Reuniões de Cúpula das Américas será possível identificar os elementos que diferenciam e que aproximam estes dois projetos que em sua essência buscavam o mesmo objetivo: o fortalecimento da integração regional. A importância deste trabalho reside na necessidade de desenvolver uma visão mais abrangente do rumo que o Brasil vem dando para os processos de integração regional, e de qual a postura que o País vem assumindo neste processo. Somente a partir desta compreensão será possível entender a situação do Brasil no contexto regional e dar continuidade aos processos de integração.

\section{A Política Externa de FHC para o continente americano}

Quando Fernando Henrique Cardoso assume a presidência do Brasil, em janeiro de 1995, o processo de integração sul-americano ainda era relativamente recente. Neste sentido, é importante lembrar que a criação do Mercosul, em 1991, ocorre dentro do contexto da busca de um novo modelo de desenvolvimento tanto pelos governos brasileiro e argentino, e que substituiria o desenvolvimentismo pelo neoliberalismo. Ou seja: apesar de surgir como uma alternativa à dependência econômica dos EUA, o projeto de integração regional nada tinha de anti-sistêmico. Pelo contrário, o governo brasileiro via o Mercosul como o primeiro de três grandes passos na busca de uma maior inserção ao sistema internacional: o segundo passo seria expandir o projeto para o restante do continente sul-americano, para então buscar uma atuação mais ativa nos foros internacionais. 
Antes mesmo de assumir a presidência, FHC já tinha uma atuação importante na defesa deste processo de integração, como Ministro das Relações Exteriores do governo Itamar Franco. Neste período, o Mercosul se tornou "prioridade número um" da agenda internacional brasileira. Também foi neste período que foi criada a ALCSA, a Área de Livre Comércio Sul-Americana, com o objetivo de liberalizar o comércio de bens entre os países sul americanos. Apesar de não ter tido continuidade, este projeto serviria de modelo para a IIRSA, a CASA e a Unasul (PECEQUILO, 2012).

Após vencer as eleições, mas ainda antes de ser empossado, FHC acompanhou o presidente Itamar Franco à Cúpula de Miami, realizada em dezembro de 1994. Foi nesta ocasião que o governo norte-americano apresentou o projeto da Área de Livre Comércio das Américas (Alca), que viria a pautar a política externa brasileira ao longo de todo o governo Cardoso. Na ocasião, apesar de ter sido praticamente obrigado a participar das negociações a fim de evitar uma posição isolada, o governo brasileiro "representou a maior e mais consistente resistência ao projeto norte-americano" (SIMÃO, 2009, p.7), com a defesa dos projetos de integração regionais:

Assim, logo que assumiu, FHC foi confrontado pelo dilema ALCA/Mercosul e a reavaliação das políticas de Itamar (Autonomista) e de Collor (Alinhamento Automático). Em resposta a este dilema, de 1995 a 1999, a política externa para os EUA foi caracterizada pelo alinhamento pragmático com focos de resistência: a preservação do Mercosul diante da ALCA e a postura reivindicatória na OMC (PECEQUILO, 2012, p.243).

De fato, a preservação do Mercosul marcou de maneira decisiva a posição do Brasil em relação à Alca, o que fica muito claro nesta formulação de Celso Lafer (2001, VIGEVANI, OLIVEIRA e CINTRA, 2003, p.35), que esteve à frente do Itamaraty nos últimos dois anos do governo FHC: "para nós, [o Mercosul é] destino, parte das nossas circunstâncias. A Alca não é destino, é opção". Segundo Saraiva (2010), durante o governo Cardoso a diplomacia brasileira começou a perceber a importância dos parceiros sul-americanos para que o país pudesse se fortalecer como um global player. Ou seja, o projeto integração regional era parte de uma estratégia maior do governo, da busca da autonomia pela participação e de uma maior inserção ao sistema internacional. Ao mesmo tempo, este processo de integração exigia algumas salvaguardas, especialmente no que dizia respeito à criação da Alca. O governo brasileiro temia o choque de uma segunda onda de liberalização comercial (a primeira havia ocorrido durante o governo Collor). Por isso, vinha "trabalhando para que a negociação da Alca ocorresse lentamente, procurando ganhar tempo e realizar barganhas articuladas em outras esferas, como União Europeia e OMC" (SILVA, 2012, p.26).

A estratégia funcionou por algum tempo, mas no segundo mandato de FHC os constrangimentos impostos pelos EUA e o risco de isolamento levaram o governo brasileiro 
a tomar uma posição mais ativa no processo de negociação. A estratégia rendeu alguns ganhos no sentido da inserção de itens e conceitos de interesse do Brasil e do Mercosul, como o single undertaking ${ }^{l}$. Ainda assim, os negociadores brasileiros não conseguiram mudanças substanciais na pauta em discussão, cujo arcabouço jurídico básico deixava espaço restrito para temas não adequados ao interesse dos EUA (VIGEVANI, OLIVEIRA e CINTRA, 2003). Pecequilo detalha as principais divergências entre as posições brasileiras e norte-americanas:

Enquanto os EUA defendiam a diluição dos acordos regionais preexistentes, o Brasil optava por sua preservação (building blocks). Ao negociar, os EUA desejavam implementar os acordos paulatinamente (early harvest) e descolados da OMC, e o Brasil insistia em um projeto fechados dentro do acordo multilateral (single harvest). Persistiam discordâncias sobre quais mercados abrir e como: os EUA desejavam a liberalização dos industriais e de serviço, o Brasil defendia regras diferenciadas de abertura dependendo do tamanho e nível de produtividade das economias (e apoio aos países mais pobres com ajuda ao desenvolvimento inspirado na integração europeia), abertura de setores agrícolas e a revisão de subsídios e medidas protecionistas. De 1994 a 1999, ocorreram cinco Reuniões Ministeriais da Alca que tentaram, sem sucesso, avançar estas pautas: Denver (1996), Cartagena (1996), Belo Horizonte (1997), Costa Rica (1998) e Toronto (1999), e uma Cúpula, em 1998, em Santiago (PECEQUILO, 2013, p.76).

Ao analisar a relação com os EUA fora do âmbito das negociações da Alca, percebe-se que esta foi marcada por altos e baixos. Por um lado, o governo Cardoso construiu boas relações com o presidente Bill Clinton, com quem tinha uma afinidade pessoal. Além disso, o governo de Cardoso tomou medidas que agradaram a Washington, como a aprovação do novo Código de Propriedade Intelectual (que encerrou o contencioso das patentes) e a assinatura do Tratado de Não Proliferação de Armas Nucleares (TNP). Em abril de 2000, o governo brasileiro daria autorização para que os americanos utilizassem a base aérea de Alcântara para o lançamento de satélites e equipamentos (BARRETO, 2012a).

Destaca-se ainda a iniciativa brasileira de enquadrar os atentados de 11 de setembro de 2001 como uma agressão a todo continente americano, nos termos do Tratado Interamericano de Assistência Recíproca (TIAR). Mas a partir de 1998, com a crise envolvendo o impeachment do presidente Clinton, seguida pela "Guerra ao Terror" do presidente Bush, houve uma relativa estagnação nas relações entre Brasil e EUA. As negociações da ALCA foram praticamente suspensas, e a política norte-americana para a América Latina se voltou para as questões de segurança, em especial para o Plano Colômbia², aprovado pelo

\footnotetext{
${ }^{1}$ Um compromisso único, e não em partes. Ou seja, o acordo só será fechado quando houver consenso em todas questões.

${ }^{2}$ Projeto financiado pelos EUA, em parceria com o governo da Colômbia, para combater o tráfico de drogas em território colombiano.
} 
Congresso americano no ano 2000. Na ocasião, apenas o Brasil e a Venezuela não aceitaram ceder seus territórios para a instalação de bases militares norte-americanas. Outro ponto de atrito foram as acusações do governo americano de que haveriam terroristas na tríplice fronteira entre Brasil, Paraguai e Argentina.

Destaca-se ainda o contencioso com os EUA envolvendo a quebra de patentes de medicamentos para o tratamento da Aids, iniciado no ano 2000. O governo brasileiro exigia das grandes empresas farmacêuticas, a maioria norte-americanas, o direito de quebra das patentes a fim de permitir o tratamento das populações menos favorecidas. Um acordo só seria obtido em junho de 2001:

Utilizando o argumento de que o bem público deve prevalecer sobre o lucro, o país legitimou sua demanda e obteve simpatia da maioria dos outros países, da ONU, particularmente da Organização Mundial da Saúde (OMS), e de organizações não-governamentais (ONGs) envolvidas com os temas de saúde pública e de direito humanitário. Os Estados Unidos aceitaram o acordo, admitindo a possibilidade de quebra de patentes em questões de saúde pública de países em desenvolvimento (VIGEVANI, OLIVEIRA e CINTRA, 2003, p.50).

Diante das dificuldades na relação com os EUA, a resposta de FHC foi uma revisão de sua política externa, com o retorno de um viés autonomista (BARRETO, 2012a). Contribui para isso a frustração com a falta de avanços nas pautas brasileiras. Apesar dos esforços do governo Cardoso para ganhar credibilidade no sistema internacional, o Brasil não recebeu apoio dos EUA em mais uma onda de reformas do Conselho de Segurança da ONU, ocorrida em 1995. "A mesma estagnação se viu nas negociações da OMC, que terminaram sem avanços em Cingapura, em 1995, e na Rodada do Milênio em Seattle, em 1999" (PECEQUILO, 2013, p.76).

É neste contexto que Cardoso dá um novo impulso ao processo de integração regional. Em 1999, quando toma posse pela segunda vez diante do Congresso Nacional, ele já deixa claro que a preservação do Mercosul é uma pré-condição para qualquer negociação com os Estados Unidos em relação à Alca. Na ocasião, o presidente afirma que o bloco é uma "dimensão prioritária e irreversível de nossa diplomacia” (PRESIDÊNCIA DA REPÚBLICA, 1999).

Mas naquele mesmo ano (1999) o Mercosul passaria por um de seus períodos mais delicados em função da crise entre Brasil e Argentina, desencadeada pela forte desvalorização do Real ${ }^{3}$. Enquanto muitos criticavam o Mercosul como um empecilho ao desenvolvimento brasileiro, FHC tomou o caminho oposto, e reafirmou seu compromisso com o processo de integração ao convocar a Primeira Reunião de Presidentes da América do

\footnotetext{
${ }^{3}$ Em 1999 o governo brasileiro desvalorizou o real sem consultar previamente os países vizinhos, o que impactou diretamente a economia argentina. Em retaliação, o presidente Menem criou barreiras à entrada de produtos brasileiros no país (SARAIVA, 2010).
} 
Sul, em Brasília. Para Pecequilo (2012, p.267 e 268), esta atitude "inseriu uma renovada dinâmica nos processos regionais e criou bases diferenciadas de cooperação, vide a IIRSA e os investimentos do BNDES em seu âmbito". A Cúpula de Brasília ocorreu entre os dias 31 de agosto e $1^{\circ}$ de setembro de 2000, e teve como principais temas a integração econômica, infraestrutura e fortalecimento das democracias (SARAIVA, 2010).

Também foi a partir deste encontro que o governo brasileiro consolidou o redirecionamento de sua matriz energética para os países vizinhos. O Brasil, que até os anos 1980 era muito dependente dos países do Golfo Pérsico, na década de 1990 passou a priorizar as importações da Argentina e da Venezuela. O governo FHC também fora responsável por grandes projetos de integração física, como a interligação das redes de energia elétrica e o gasoduto que liga a Bolívia ao Brasil (VIGEVANI, OLIVEIRA e CINTRA, 2003). A preocupação com o tema da infraestrutura durante a Cúpula de Brasília se materializou na apresentação da proposta da Iniciativa para a Integração da Infraestrutura Regional Sul-Americana (IIRSA). Também é neste encontro que nasce o projeto da Comunidade Sul-Americana de Nações (Casa), com o objetivo de unir dois blocos econômicos: o Mercosul e a Comunidade Andina de Nações (CAN). A Casa seria institucionalizada durante o governo Lula, e mais adiante daria origem à União de Nações Sul-Americanas (Unasul).

Ainda em relação à política externa do Presidente Fernando Henrique para o entorno regional, cabe lembrar as tentativas de se estabelecer um acordo econômico entre o Mercosul e a União Europeia (UE). Este acordo, até hoje inconcluso, seria uma alternativa ou uma resposta ao projeto norte-americano da Alca (GRATIUS, 2007). A aproximação com a UE tinha ainda outra vantagem: ao contrário dos norte-americanos, os europeus privilegiavam a negociação bloco a bloco (VIGEVANI, OLIVEIRA e CINTRA, 2003).

Também cabe destacar o crescente papel do Brasil como árbitro regional, como no caso do conflito fronteiriço entre Peru e Equador (1996). Já em 1998, o Brasil defendeu a democracia paraguaia e o Mercosul invocou a Cláusula Democrática. "Com isso o bloco foi ganhando contornos mais políticos" (BERRINGER, 2014, p.108). Postura semelhante foi adotada durante a crise venezuelana de 2002, quando o governo de FHC atuou de forma coordenada com o já eleito presidente Lula para defender a ordem democrática (VIGEVANI, OLIVEIRA e CINTRA, 2003).

Apesar de ter assumido a dianteira no processo de integração sul-americano, o governo Fernando Henrique resistia em falar sobre uma liderança brasileira. O tema era tratado com imensa cautela no meio diplomático, o que fica claro na declaração do então Chanceler Lampreia:

[o] Brasil não quer assumir a liderança regional nem quer se candidatar a um posto de liderança da América do Sul". No seu entender, esta atitude "levaria interpretações e confusões não desejadas por nós, como a de querer uma condição hegemônica (LAMPREIA, 24 de agosto de 2000, apud SANTOS, 2014, p.152 e 153). 
Vigevani e Cepaluni (2007, p.301) reforçam esta postura ao explicar que "para o grupo formulador da política externa no governo FHC, o eventual papel do Brasil como líder era visto como consequência da gradual proeminência econômica do país e deveria ser limitado à região, por causa da escassez de recursos (...) disponíveis para a ação externa do Estado".

Ou seja, a análise da política externa do governo FHC para o entorno regional demonstra a importância que o Presidente dava ao processo de integração, especialmente ao Mercosul. Diante de um momento de crise do bloco, Cardoso apostou na ampliação do projeto de integração regional de modo a incluir todos os países sul-americanos. Mas cabe lembrar que o projeto de Fernando Henrique era de um regionalismo aberto, que servisse de trampolim para uma maior inserção do Brasil ao cenário internacional. O trecho a seguir define bem esta relação entre universalismo e o regionalismo durante o governo Cardoso:

[...] o universalismo dos anos noventa se expressa primordialmente no regionalismo: é nesta área que o Brasil encontrou seu principal espaço de reafirmação de autonomia, na resistência à integração hemisférica, no processo de integração subregional do Mercosul e nas suas novas iniciativas na América do Sul (MELLO, 2000, p. 112, VIGEVANI, OLIVEIRA e CINTRA, 2003, p.46).

Este equilíbrio delicado entre regionalismo e universalismo se expressa em um elemento recorrente na política externa de Cardoso: cautela. A cautela é a palavra de ordem tanto nas negociações da Alca como na discussão sobre uma possível liderança regional do Brasil. Desta forma, podemos entender que a estratégia do governo Cardoso para o entorno regional consistia em fortalecer o processo de integração sul-americano, mantendo ao mesmo tempo boas relações com os Estados Unidos e deixando as portas abertas para negociações com outras regiões do globo.

\subsection{Discursos do presidente FHC nas Reuniões de Cúpula das Américas}

O político e sociólogo Fernando Henrique Cardoso assumiu a presidência do Brasil em janeiro de 1995, após ter sido Ministro das Relações Exteriores (1992-1993) e Ministro da Fazenda (1993-1994) do Presidente Itamar Franco. Como Ministro da Fazenda, fora responsável pela implementação do Plano Real, criado em 1994, que levou ao fim da hiperinflação que assolava o Brasil há 15 anos. Ao mesmo tempo, a economia brasileira passava por um processo de reintegração ao mercado internacional, graças à renegociação da dívida externa no contexto do Plano Brady4, implementado em 1994. (LOPREATO, 2014).

\footnotetext{
${ }^{4}$ Tinha como elemento essencial a novação da dívida objeto de reestruturação, mediante a troca por bônus de emissão do governo do país devedor, que contemplavam abatimento do encargo da dívida, seja sob a forma de redução do seu principal, seja por alívio na carga de juros. No caso brasileiro, o acordo
} 
No plano internacional, o mundo ainda vivia os reflexos do período pós-Guerra Fria, em que vigorava a ideia da "criação de uma 'Nova ordem mundial' sustentada na liderança dos EUA e na governança multilateral (...)" (PECEQUILO, 2008, p.137). Como sustenta Harvey, parecia que o mundo tinha finalmente atingido certa acomodação:

Fukuyama profetizou que o fim da história estava próximo. Teve-se por um breve momento a impressão de que Lenin estava errado e de que Kautsky poderia estar certo - um ultra-imperialismo baseado numa colaboração 'pacífica' entre todas as grandes potências imperialistas (agora simbolizada pelo chamado G7, ampliado para o G8 a fim de incorporar a Rússia, embora sob a hegemonia da liderança dos Estados Unidos) era possível -, bem como de que o caráter cosmopolita do capital financeiro (simbolizado pelas reuniões do Fórum Econômico Mundial em Davos) seria sua ideologia de base (HARVEY, 2005, p. 63).

Silva também descreve este novo consenso ideológico, explicitado no chamado Consenso de Washington ${ }^{5}$ e na ideia do livre mercado como promessa de desenvolvimento. Segundo o autor, o sistema internacional do final dos anos 1990 foi marcado pela "[...] a formação de blocos econômicos, maior internacionalização do capital (centralização e concentração internacional do capital) e pelo acirramento do processo de globalização (SILVA, 2008, p. 65-66).

A II Reunião de Cúpula das Américas acontece neste contexto, no dia 18 de abril de 1998, em Santiago no Chile. Quatro anos antes, na primeira reunião de cúpula, havia sido apresentada a proposta da Alca. O discurso de Fernando Henrique na capital chilena apresenta um tom otimista, onde o presidente defende um processo de integração alicerçado na solidariedade e no combate à pobreza. Cardoso começa por invocar os valores que seriam comuns aos países ali representados - igualdade, solidariedade e liberdade - e fala da necessidade de que este o projeto de integração vá além das questões econômicas:

De alguna maneira, o espírito que nos traz aqui é o espíritu de criação de uma nova comunidade, é constitucional. [...] se o impulso foi econômico inicialmente, dizia, pouco a pouco, sem abandonar a preocupação com a economia, que é fundamental, deixamos de falar apenas em taxas aduaneiras -em "aranceles" "tariffs"-e passamos a falar uma

firmado em abril de 1994 referia-se apenas à parte da dívida do setor público com bancos comerciais estrangeiros. O desconto efetivo associado ao acordo foi de 7,6\% do valor da dívida afetada pelo acordo (BANCO CENTRAL DO BRASIL, 2016)

${ }^{5}$ Consenso de Washington: segundo John Williamson, que cunhou o termo, se refere ao às principais políticas recomendadas pelas instituições de Washington aos países latino-americanos em 1989. As principais medidas consistiam no ajuste fiscal, direcionamento dos gastos públicos para áreas que tragam tanto alto retorno econômico como melhora na distribuição de renda, reforma tributária, liberalização da taxa de juros, liberalização comercial, taxa de câmbio competitiva, privatizações, desregulamentação e segurança no direito à propriedade (WILLIAMSON, 2000). 
linguagem que toca mais ao coração dos nossos povos: pobreza, justiça, luta contra a impunidade, luta contra a droga, decência na administração pública, coisas concretas que realizam na prática, com um século de atraso, o que foi o sonho daqueles que fundaram, constitucionalmente, as idéias fundamentais da democracia, e que são a expressão mesma, moderna, do mundo ocidental. (MINISTÉRIO DE RELACIONES EXTERIORES, 1998, p.519).

Percebe-se aqui a adesão de FHC aos "valores ocidentais", como democracia, igualdade e liberdade, e a tentativa do presidente de adequar seu discurso aos temas discutidos no âmbito das organizações internacionais. Importante lembrar que nesta "Nova Ordem Mundial" pós-Guerra Fria, os países em desenvolvimento passaram por um intenso processo de abertura econômica e de "normalização". Em especial na América Latina, este processo foi acelerado pela crise da dívida externa e pela pressão exercida pelo FMI e pelo Banco Mundial. De acordo com Rodrik (1994 apud MILNER, 1999, p. 92, tradução nossa) "desde o início da década de 1980, países em desenvolvimento afluíram em bando para o livre comércio como se este fosse o Santo Graal do desenvolvimento econômico [...]".

No Brasil (assim como em grande parte dos países latino-americanos) estas transformações marcaram a transição do paradigma desenvolvimentista de substituição de importações para o paradigma neoliberal. Ou, como coloca Silva (2012), o governo FHC marca o abandono da "autonomia pela distância", característica do período desenvolvimentista, pela "autonomia pela integração", que rechaçava o isolamento e via a inserção ao sistema internacional como o único caminho para o desenvolvimento. Para isso, as prioridades eram a aplicação de reformas políticas e econômicas, a participação em organizações multilaterais como a ONU e o GATT, a adesão ao Consenso de Washington e abandono do discurso terceiro-mundista. É este processo de adequação às normas internacionais que recebeu o nome de "normalização".

Silva (2012) destaca que este processo foi menos intenso no Brasil do que nos demais países da região, em parte devido à resistência do empresariado nacional e da classe trabalhadora. Ainda assim, as reformas incluíram a privatização de grandes empresas estatais, como a Telebrás, Companhia Vale do Rio do Doce, a Usiminas e diversos bancos estaduais. Isto resultou em um intenso processo de internacionalização da economia brasileira. Entre os anos de 1989 e 2000, a participação das empresas estrangeiras entre as maiores do Brasil passou de $30 \%$ para $48 \%$. As companhias internacionais se tornaram responsáveis por $56 \%$ do faturamento, $49 \%$ das importações e $67,2 \%$ das exportações brasileiras (SARTI \& LAPLANE, 2003, apud BERRINGER, 2014).

No trecho a seguir, em que Cardoso fala sobre a convivência entre a Alca e os processos de integração já existentes, o presidente faz nova defesa dos valores ocidentais e do livre comércio: 
De Miami a Santiago, se houve uma transformação, se houve uma evolução, foi nessa direção e foi no conhecimento recíproco. Se antes havia, talvez, alguma desconfiança de que a zona de livre comércio nas Américas talvez dificultasse o Mercosul ou, quem sabe, o NAFTA fosse o caminho mais adequado, e que nós nos somássemos ao NAFTA - ou, quem sabe, o CARICOM, um pouco à margem, ou o Acordo Centro-Americano de Livre Comércio, cada um olhando para o outro para medir suas vantagens e desvantagens. De repente percebeu-se que não, que o que nós fizemos, no Mercosul e em todos os outros blocos regionais são passos constitutivos para ver este grande espírito americano que é a zona de livre comércio, compreendida como nós a compreendemos hoje, como uma zona de liberdade, de paz e, sobretudo, de igualdade concreta na educação, no atendimento aos mais carentes, na luta contínua contra a pobreza (MINISTÉRIO DE RELACIONES EXTERIORES, 1998. p. 519 e 520).

Chama a atenção o extremo otimismo com que FHC fala sobre a configuração da Alca: é como se a questão já estivesse resolvida, e os impasses entre os países e blocos já estivessem solucionados. Ainda assim, Fernando Henrique expõe seu entendimento de que a criação da Alca não deva inviabilizar os demais blocos regionais, com especial destaque para o Mercosul.

Na continuidade do discurso, o Presidente dá grande destaque para a necessidade de combater a pobreza, e afirma que "há pobres porque nós não estamos ainda moralmente comprometidos com a luta contra a pobreza. Já dispomos de recursos suficientes para, se estivermos juntos, lutarmos efetivamente contra a pobreza e nada .." (MINISTÉRIO DE RELACIONES EXTERIORES, 1998, p.520). FHC segue afirmando que por isso:

“[...] não queremos armamentos, não queremos competições. Queremos, sim, solidariedade, novas formas de solidariedade para que nós possamos usar os instrumentos racionais de que dispomos, e os recursos materiais de que começamos a dispor, para mudar efetivamente, não o mundo em termos de idéias, mas a vida concreta da população mais pobre [...]” (MINISTÉRIO DE RELACIONES EXTERIORES, 1998, p.520).

Ao mesmo tempo em que faz uma autocrítica, o presidente Fernando Henrique manda um recado ao governo norte-americano, no sentido do tipo de projeto que o continente deseja. Ao invés de um projeto voltado para a questão da segurança, uma iniciativa cujo foco esteja na melhoria das condições sociais da população. Este deve ser um esforço coletivo, e não uma ação unilateral. A seguir, FHC volta a mostrar sua preocupação quanto ao tema da segurança regional:

[...] mas gostaria de dizer, como um dos Países Garantes do Protocolo do Rio de Janeiro, que nada nos satisfará mais no nosso continente do que a finalização desse processo de tranqüilização entre o Peru e o Equador - e os Presidentes de Peru e do Equador são 
merecedores dos nossos agradecimentos pela maneira corajosa como têm desenvolvido os trabalhos que vão nos levar a que possamos dizer, com toda tranqüilidade: este é um hemisfério em que não há questões de fronteira (MINISTÉRIO DE RELACIONES EXTERIORES, 1998, p.521).

Importante lembrar que a Reunião de Cúpula de 1998 aconteceu poucos meses antes de os governos do Equador e do Peru fecharem um acordo de paz para pôr fim à uma disputa fronteiriça entre os dois países, que havia desencadeado uma guerra em 1995. FHC termina seu discurso tratando de um tema delicado: a ausência de Cuba no encontro:

E também não gostaria de deixar de dizer uma palavra, uma que seja, sobre as muitas dúvidas e indagações que ouvi pelos corredores. Por que não todos? Falta talvez ainda um país. E esse país que falta firmou aqui, em Valparaíso, um compromiso com a democracia. Esse país que falta tem um contrato social, preocupa-se profundamente com educação e com saúde. Por que não dar os passos da democracia, que são tão bem-vindos por todos, para que amanhã nós todos possamos dizer: "Nuestra América es una sola, democrática y hecha de hermanos" (MINISTÉRIO DE RELACIONES EXTERIORES, 1998, p.521).

Interessante observar a posição dúbia de FHC. Por um lado, faz uma crítica à ausência de Cuba (expulsa da OEA em 1962) e elogia o compromisso deste país com a saúde e a educação de seu povo. Por outro, culpa o próprio governo cubano pela sua ausência na reunião: afinal, porque não adere a democracia? Ou seja, a crítica de Fernando Henrique não recai sobre a postura da OEA de não convidar o presidente cubano, e sim sobre a postura do governo cubano de não se ajustar às exigências da Organização. Sob esta ótica, o presidente brasileiro instiga Cuba a passar pelo mesmo processo de normalização que ele incutiu ao Brasil, a fim de melhor se ajustar ao sistema internacional. Ou seja, o que mais chama atenção neste discurso de FHC é seu tom amigável, otimista e conciliador. Fernando Henrique evita entrar em atrito com qualquer país, e se mostra confiante no sucesso da criação de uma Área de Livre Comércio das Américas.

Já a III Reunião de Cúpula das Américas aconteceu em Quebec, no Canadá, no 20 de abril de 2001, e foi marcado por protestos de grupos ligados aos direitos humanos, defesa do meio ambiente e sindicatos. Eles criticavam o processo de globalização e os impactos do livre comércio para o meio ambiente e as sociedades.

Fernando Henrique inicia seu discurso lembrando um fato que acontecera algumas semanas antes no Brasil, quando uma equipe de antropólogos fizera uma expedição por áreas habitadas por índios isolados, em meio à floresta amazônica. Quase ao mesmo tempo, representantes de 34 países se reuniam em Quebec para tratar do tema da "conectividade": 
De um lado, comunidades ainda isoladas. De outro, a revolução da Internet. São fatos que me fazem refletir sobre a sabedoria da pequena letra "s" ao final do título deste nosso encontro: a Cúpula das Américas. Porque somos, verdadeiramente, um continente plural, um continente de diversidade: diversidade de renda, de padrões de vida, de língua, [...]. Não existe apenas uma, mas várias Américas, talvez 34 Américas ou melhor 35, aí incluído, como esperamos possa ocorrer em futuro não distante, o povo amigo e irmão de Cuba. (PRESIDÊNCIA DA REPÚBLICA, 2001, p. 241 e 242).

Não é à toa que FHC começa seu discurso tratando da diversidade dos países americanos. Como será visto adiante, este tema voltará a ser invocado na fala de Cardoso, como uma forma de resistência ao projeto da Alca. Assim como no discurso anterior, o presidente menciona a ausência de Cuba. Desta vez, porém, sem instigar o governo cubano a democratizar-se, mas apenas demonstrando seu desejo de que o país possa ser novamente integrado à OEA. Na sequência, FHC relembra o período das ditaduras latino-americanas, e afirma que o processo de integração só é possível porque ocorre em um contexto de legitimidade democrática:

E essa legitimidade tem dois lados: internamente, o funcionamento e o aperfeiçoamento progressivo das instituições do Estado de Direito; externamente, o respeito recíproco e a prevalência do diálogo sobre todas as formas de coerção e uso da força. As grandes questões de nosso tempo se resolverão pelo diálogo e pelo entendimento, ou não se resolverão de forma alguma. Pelo diálogo e pelo entendimento, que levem a maior acesso aos mercados e às tecnologias, bem como a maiores investimentos nos países menos desenvolvidos da região, poderemos responder às aspirações dos povos deste continente, e com mais urgência, às aspirações dos mais pobres e mais vulneráveis. Pelo diálogo e pela cooperação poderemos responder a desafios contemporâneos, como o de assegurar aos que sofrem com a Aids tratamento ao menor custo possível. Como demonstra o êxito do programa brasileiro nesse carnpo, já dispomos de meios para aumentar a esperança e melhorar a vida dos que têm o vírus HIV. Não podemos deixar de utilizá-los, e de utilizá-los em toda a escala, inclusive cooperando com outros países em desenvolvimento afetados por essa doença (PRESIDÊNCIA DA REPÚBLICA, 2001, p.243).

Vários elementos deste trecho merecem destaque. Em primeiro lugar, a defesa intransigente do diálogo e do respeito entre os países. Não se pode deixar de relacionar este elemento ao Plano Colômbia, cujas as operações haviam iniciado no ano 2000, e que levou à instalação de diversas bases militares dos EUA no continente sul-americano. Na ocasião, apenas Brasil e Venezuela se negaram a ceder território para estes fins. Ou seja, o que Fernando Henrique está fazendo é repudiar qualquer forma de ingerência dos Estados Unidos nos assuntos da região. Cardoso também levanta o tema dos medicamentos para o 
tratamento do HIV, que neste mesmo período era motivo de discórdia entre Brasil e EUA. Como visto anteriormente, a questão da quebra das patentes destes medicamentos só seria resolvida em junho de 2001, com uma vitória do Brasil. Ou seja, ao contrário do que foi observado no discurso anterior, desta vez FHC não hesita em trazer à tona um tema sensível ao governo norte-americano. Na sequência, Cardoso volta a falar da diversidade que caracteriza a região:

Nem a integração hemisférica, nem o processo de globalização podem significar um declive inexorável rumo à homogeneidade cultural. Nesse plano, a diferença é um valor em si mesma. Mas se desejamos caminhar para uma efetiva integração do hemisfério, devemos colocar-nos como tarefa a eliminação da diversidade que é injusta: a profunda desigualdade de renda e de condições de vida, tanto dentro dos países como entre os países. Nosso objetivo deve ser o de uma Comunidade das Arnéricas. E "comunidade" pressupõe consciência de um destino comum e, portanto, eliminação de assimetrias e garantia de oportunidades iguais para todos. Pressupõe também reconhecer que os caminhos históricos de cada povo para moldar suas instituições económicas são variáveis. Não há pensamento único que possa ditar os rumos das nações. O livre-comércio é um dos instrumentos. A eliminação progressiva dos obstáculos às trocas comerciais pode desempenhar um papel decisivo na criação de oportunidades para o crescimento económico e para a superação das desigualdades. Assim concebemos no Brasil a possibilidade de uma Alça. Assim temos realizado, com êxito, a construção do Mercosul, que para o Brasil é uma prioridade absoluta, uma conquista que veio para ficar, e que não deixará de existir pela participação em esquemas de integração de maior abrangência geográfica (PRESIDÊNCIA DA REPÚBLICA, 2001, p.243 e 244).

Mais uma vez, FHC defende o direito à autodeterminação dos povos americanos, de modo que cada país possa escolher o que for melhor para si. Dentro deste mesmo raciocínio, Cardoso demostra uma visão crítica tanto do processo de integração como da globalização. Ao rejeitar um "pensamento único", Fernando Henrique afirma que o livre comércio é "um dos instrumentos". Ou seja, não o único instrumento de integração, e não pode ser imposto ao continente como o único caminho possível. Este maior ceticismo do presidente em relação ao sistema internacional está inserido em um processo de reorientação da política externa brasileira que ocorreu ao final do segundo mandato de FHC. A globalização, antes vista como um processo benéfico, passa a ser descrita como uma "globalização assimétrica", cujos frutos são distribuídos de forma desigual entre países ricos e em desenvolvimento. A "guerra contra o terrorismo" e o aumento do unilateralismo norte-americano foram alguns dos fatores que interferiram na visão do governo FHC sobre o sistema internacional: 
Acreditamos que o ataque de 11 de setembro de 2001 e as dificuldades advindas da Rodada de Doha da OMC foram choques externos que colaboraram para a alterção da política exterior brasileira, modificando em alguns pontos o curso do final do governo FHC, adiantando elementos de mudança que só ficariam mais claros na administração Lula da Silva (VIGEVANI e CEPALUNI, 2007, p.280).

Soma-se a isso a promessa não cumprida do liberalismo: a do desenvolvimento econômico. Segundo Salama (2012), a liberalização comercial adotada a partir dos anos 1980 pelas economias emergentes latino-americanas não produziram um aumento das taxas de crescimento. Pelo contrário, a taxa é em média inferior à verificada entre 1955-1980, período marcado por políticas protecionistas.

Por fim, o presidente faz uma defesa eloquente do Mercosul, utilizando o termo "prioridade absoluta". Trata-se de uma mensagem muito mais clara aos Estados Unidos do que aquela dada na Reunião de Cúpula de Santiago. O presidente vai além nos condicionantes da Alca:

A Alça será bem-vinda se sua criação for um passo para dar acesso aos mercados mais dinâmicos; • se efetivamente for o caminho para regras compartilhadas sobre anti-dumping; • se reduzir as barreiras não-tarifárias; • se evitar a distorção protecionista das boas regras sanitárias; • se, ao proteger a propriedade intelectual, promover, ao mesmo tempo, a capacidade tecnológica de nossos povos. E, ademais, se for além da Rodada Uruguai e corrigir as assimetrias então cristalizadas, sobretudo na área agrícola. Não sendo assim, seria irrelevante ou, na pior das hipóteses, indesejável. Se tivermos a sabedoria de fazê-la bem feita, a Alça pode vir a ser um avanço na promoção do desenvolvimento e da justiça social. Insistiremos em que os benefícios do livre-comércio se repartam igualmente entre todos os participantes, para que as aberturas ao comércio sejam recíprocas e conduzam à atenuação, e não ao agravamento, das disparidades em nossa região (PRESIDÊNCIA DA REPÚBLICA, 2001, p.244).

Percebe-se aqui uma postura bem diferente daquela adotada no discurso da reunião anterior. FHC não foi mais enfático apenas na defesa do Mercosul, mas também na rejeição a um projeto da Alca que atenda prioritariamente aos interesses norte-americanos. Neste caso, o projeto seria “indesejável". Cardoso também faz novas referências a temas sensíveis no relacionamento entre o Brasil e os EUA, como é o caso da propriedade intelectual e do protecionismo aos produtos brasileiros. A seguir, Fernando Henrique faz uma crítica ao livre-comércio como um objetivo em si mesmo:

Quando se tem presente que o livre-comércio é um instrumento para os objetivos de desenvolvimento e justiça, torna-se evidente que seria um erro, e um erro grave, condicioná-lo a certos padrões de desenvolvimento social. Seria pretender que o desenvolvimento 
seja uma condição prévia pára o próprio desenvolvimento. Seria o que se chama, em lógica, uma "petição de princípio". Em bom português, seria colocar o carro na frente dos bois (PRESIDÊNCIA DA REPÚBLICA, 2001, p.245).

Este trecho se insere dentro do contexto da frustração de FHC com as políticas neoliberais de abertura comercial e inserção internacional. O presidente também faz referências às regras injustas do comércio internacional, ao afirmar que a luta pela proteção ambiental e pelas normas trabalhistas não pode "converter-se em um pretexto para práticas protecionistas ou distorsivas do comércio" (PRESIDÊNCIA DA REPÚBLICA, 2001, p.245). Fernando Henrique conclui seu discurso fazendo referência ao protesto que acontece em Quebec, segundo ele "motivado pelo temor de uma Alça ou de uma globalização sem "rosto humano"” (PRESIDÊNCIA DA REPÚBLICA, 2001, p.246). E termina dizendo:

O Brasil afirma aqui o seu compromisso de trabalhar com afinco e com determinação para a construção, nas Américas, de uma comunidade de nações democráticas, voltada para a liberdade, a justiça e o desenvolvimento. Nações democráticas que se reencontrem não como partes de um mercado, apenas, mas de uma civilização de base humanística (PRESIDÊNCIA DA REPÚBLICA, 2001, p.246).

Ou seja, apesar das duras críticas ao projeto da Alca, FHC faz questão de garantir que o Brasil segue na mesa de negociações. Identificamos neste jogo discursivo a estratégia de prolongar as negociações, de modo a evitar tanto o isolamento como a submissão aos interesses norte-americanos. Percebe-se, portanto, que o tom do discurso de FHC passou por uma mudança significativa da Segunda para a Terceira Cúpula das Américas: as palavras que antes eram otimistas e sutis, tornaram-se duras, críticas e objetivas. Em 2001, Fernando Henrique não hesita em defender suas posições em relação à Alca, rejeitar qualquer tipo de interferência nos assuntos da região e tratar de temas que estão em disputa com os EUA.

\section{A Política Externa do governo Lula para o continente americano}

Ao assumir o Palácio do Planalto, o presidente Lula manteve a integração regional como prioridade da política externa brasileira. Algumas mudanças em relação ao governo FHC, no entanto, precisam ser destacadas. A principal delas é a nova postura do governo brasileiro no sentido de ocupar um papel de liderança na região. Ao contrário de Cardoso, que tratava esse tema com imensa cautela, o governo Lula tratava a questão como um fenômeno natural:

Às vezes nos perguntam se o Brasil quer ser líder. Nós não temos pretensão à liderança, se liderança significa hegemonia de qualquer espécie. Mas, se o nosso desenvolvimento 
interno, se as nossas atitudes, [...], de respeito ao direito internacional, da busca de solução pacífica para controvérsias, de combate a todas as formas de discriminação, de defesa dos direitos humanos e do meio ambiente, se essas atitudes geram liderança, não há por que recusála. E seria, certamente, um erro, uma timidez injustificada (AMORIM, 9 de janeiro de 2003, apud SANTOS, 2014, p.154).

A busca de uma posição de liderança não se restringia ao continente sul-americano. Segundo Saraiva (2010), o principal objetivo do Brasil durante o governo Lula era assumir a posição de líder regional e ser visto como uma potência global. A autora credita esta pretensão à influência da corrente autonomista do Itamaraty na política externa do governo Lula, que via os processos de integração como uma forma de acessar os mercados internacionais e fortalecer a posição do Brasil na economia mundial.

Este pensamento fica claro na fala de Lula, em 2005, quando o Presidente afirmou que o país "tinha uma posição de liderança na América do Sul e América Latina”, e que apesar dos problemas sociais e das limitações militares, "o Brasil podia ser globalmente um ator pleno e colaborar para a construção de 'uma nova relação de forças no plano internacional"” (DA SILVA, apud BARRETO, 2012b, p.18). O presidente estava disposto a arcar com os custos desta liderança, e defendia que, por ser a maior economia da região, cabia ao Brasil ser generoso na relação com os parceiros (SANTOS, 2014, p.155).

A busca pela liderança leva ao aumento da intensidade das relações com os vizinhos, na comparação com o governo anterior. Em entrevista concedida em julho de 2003, o Ministro das Relações Exteriores do governo Lula, Celso Amorim, afirmou que "o Presidente Lula tem buscado a integração da América do Sul com uma intensidade que nunca ocorreu na história. Em apenas cinco meses de governo, sete presidentes sulamericanos vieram ao Brasil, algo que nunca ocorreu antes (AMORIM, 2 de junho de 2003, apud SANTOS, 2014, p.149). O chanceler cita ainda a realização de duas reuniões, em menos de dois meses, entre chanceleres dos países da Comunidade Andina e o Mercosul, e o convite recebido pelo presidente Lula para participar da reunião de cúpula da Comunidade Andina.

Outro fato que confirma a prioridade dada à integração sulamericana foi a criação da Subsecretaria Geral da América do Sul (SGAS), que concentrou as negociações com a Alca e a União Europeia. Isto significou uma importante transformação no organograma do Itamaraty, ao superar a tradicional separação entre as esferas política e econômica dentro da estrutura do Ministério das Relações Exteriores (SANTOS, 2014). Segundo Amorim, essa mudança de organograma foi um “detonador de uma certa ótica, quer dizer, nós vamos fazer as negociações na Alca, as negociações com a União Europeia, pela ótica do Mercosul e da América do Sul" (AMORIM, 21 de julho de 2003, apud SANTOS, 2014, p.151).

Outra mudança importante implementada pelo governo Lula é a da "sul-americanização" das relações com o entorno regional. A criação de um espaço econômico comum no continente já estava entre as prioridades de FHC, mas a partir do governo Lula se tornou 
a principal prioridade da política externa brasileira (SANTOS, 2014). Segundo Gratius (2007), a intensificação das relações com os países sul-americanos está inserida em uma estratégia mais ampla, de ampliação das relações Sul-Sul:

O objetivo principal da atual política externa é acentuar a independência do Brasil através da construção de alianças estratégicas com outras potências emergentes a nível global e com os países sul-americanos. [...]. No segundo programa (e mandato) do Governo Lula, tanto E.U.A. quanto UE ocupam a última posição na agenda externa, sendo mencionados apenas como mercados e não como sócios políticos (GRATIUS, 2007, p. 14).

Ainda segundo Gratius, a postura do governo brasileiro seria uma resposta às dificuldades encontradas nas negociações entre o Mercosul e a União Europeia e ao estancamento das discussões da Alca. Soma-se a isso a falta de avanços na Rodada de Doha da OMC. Ao mesmo tempo, o fortalecimento da integração sul-americana deve ser entendido dentro de uma "visão estratégica de transformação da ordem internacional e de busca de uma melhor inserção internacional para o Brasil, para seus vizinhos e para os países em desenvolvimento de maneira geral" (SANTOS, 2014, p.147).

Foi a partir desta perspectiva que novas organizações foram institucionalizadas na América do Sul. A principal delas é a Comunidade Sul-Americana das Nações (Casa), cujo projeto havia surgido durante a Reunião de Cúpula de Brasília, promovida pelo presidente Fernando Henrique. A organização foi institucionalizada em 2004, a partir de um acordo entre o Mercosul e a Comunidade Andina das Nações. Segundo Amorim, a formalização da Casa foi etapa fundamental para a criação de um espaço econômico integrado de dimensões continentais:

Ao vincular o Mercosul a uma área com cerca de 112 milhões de pessoas e um PIB de US\$ 270 bilhões, o acordo cria um novo patamar para o processo de integração regional. Dez dos doze países sulamericanos já estão ligados por acordos de livre comércio. A aproximação com a Guiana e o Suriname é na realidade menos complexa. Estão sendo traçados os parâmetros de uma "Comunidade SulAmericana de Nações" (AMORIM, 4 de maio 2004, apud SANTOS, 2014, p.169).

Ficou definido que a Comunidade deveria se desenvolver a partir de três pilares: diálogo político, integração econômica e comercial, e integração da infraestrutura de transportes, energia e comunicações (SANTOS, 2014). A cooperação técnica e o financiamento de projetos de infraestrutura se tornaram as principais ferramentas pelas quais o Brasil exerceu sua liderança no continente sul-americano. Segundo Saraiva (2010), o Brasil financiou diversos projetos de infraestrutura nos países vizinhos, mostrando uma preferência por relações bilaterais. O BNDES teve papel central neste processo, ao financiar obras de 
empresas brasileiras nestes países. Destaca-se também o papel do IIRSA no levantamento de recursos.

Esta postura mais agressiva do Brasil em termos econômicos não deixou de provocar reações nos governos vizinhos. Ainda segundo Saraiva (2010), alguns países desafiaram a posição de liderança do Brasil, com especial destaque para o episódio da nacionalização dos campos de produção da Petrobrás pelo governo boliviano de Evo Morales, ocorrido em 2006. Na ocasião, o Presidente Lula optou por não retaliar o país, no que foi criticado por diversos setores da opinião pública.

Em 2008, a Casa seria substituída pela União das Nações Sul-Americanas (Unasul), que se tornaria o principal canal de ação multilateral do governo brasileiro (SARAIVA, 2010). A nova organização tinha como principais objetivos: a criação de uma entidade que representasse politicamente a região; a resolução de conflitos pelos próprios países do bloco, a partir de recursos diplomáticos; manter afastadas interferências externas, como da OEA; promover a integração energética, produtiva e de infraestrutura, sem substituir o Mercosul e a Comunidade Andina (CERVO e BUENO, 2011). Ainda em 2008, foi criado o Conselho de Defesa Sul-Americano, a fim de evitar a interferência estrangeira em temas relativos à segurança regional.

Diante da priorização do projeto sul-americano, o Mercosul perdeu espaço na agenda diplomática brasileira. Ainda assim, Gratius (2007) sustenta que o Mercosul e Casa são os dois pilares que sustentam o projeto sul-americano. Para o Itamaraty, os dois projetos são compatíveis: "aquele é considerado o núcleo central da integração, e, esta, o segundo círculo" (GRATIUS, 2007, p. 16). Saraiva (2010, p.165, tradução nossa), no entanto, entende que o Itamaraty adota uma postura realista durante o governo Lula, na qual a "combinação da perspectiva sul-americana com a projeção internacional do país ganhou precedência e tem sido buscada independentemente do Mercosul". A autora complementa afirmando que a parceria com a Argentina deixou de ser uma prioridade para o Brasil durante o governo Lula.

Ainda assim, o fato é que houve tentativas de aumentar o grau de institucionalização do bloco neste período. Foi criado o Tribunal Permanente de Revisão do Mercosul e a Comissão de Representantes Permanentes. Em 2006, foi instituído o Parlamento do Mercosul, ainda que sem legislatura. Destaca-se ainda a criação do Focem, o Fundo para Convergência Estrutural. Durante a XXVII Cúpula do Mercosul, realizada em 2004 em Ouro Preto (MG), a Colômbia, o Equador e a Venezuela ingressariam na organização como Estados associados. Assim, o Mercosul passou a contar com dez participantes. Apenas a Guiana e o Suriname, dentre todos os países sul-americanos, não integravam o bloco (SANTOS, 2014). Em 2008, estabeleceu-se o Sistema de Pagamentos em Moeda Local (SML) entre Brasil e Argentina, permitindo que as importações e exportações possam ser realizadas em suas moedas nacionais (PECEQUILO, 2012).

No que diz respeito às relações com os Estados Unidos o período Lula foi marcado pela boa convivência, surpreendendo muitos analistas que esperavam do petista uma postura 
confrontacionista. Antes mesmo de tomar posse, em 10 de dezembro de 2002, Luiz Inácio Lula da Silva visitou os EUA e encontrou-se com o Presidente George W. Bush, onde deixou uma mensagem da amizade aos norte-americanos (BARRETO, 2012b). O alto nível das relações se manteve no governo Obama, tanto que o presidente brasileiro foi o primeiro líder latino-americano a ser recebido pelo presidente depois da sua chegada à Casa Branca (PECEQUILO, 2012). Um dos fatores que estimularam o bom relacionamento entre os dois países foi a presença de Hugo Chávez na Venezuela, já que o governo norte-americano apostava no Brasil para contrabalançar o líder venezuelano. Pecequilo (2012) também destaca que um dos pontos mais significativos do período Bush foi a superação das questões da ALCA e a elevação do Brasil à posição de parceiro estratégico dos EUA.

Naturalmente, nada disso impediu que houvesse pontos de atrito entre os governos brasileiro e norte-americano. Barreto (2012b) descreve as principais fontes de discordância entre os dois países: o cancelamento do acordo de utilização da Base de Alcântara; o caso do correspondente do jornal The New York Times, que escreveu um artigo ofensivo ao Presidente Lula; a continuidade da suspeita de terroristas na Tríplice Fronteira e a reciprocidade de vistos e tratamento de passageiros. Os dois países envolveram-se ainda em uma série de contenciosos comerciais, entre eles: a Emenda Byrd (aplicação de ações antidumping pelos EUA), subsídios para o algodão, imposição de salvaguardas para produtos siderúrgicos, direitos autorais e Sistema Geral de Preferências (SGP), medidas antidumping ao suco de laranja, o veto dos EUA à venda realizada pela EMBRAER à Venezuela e subsídios agrícolas.

Destaca-se ainda o posicionamento contrário do Brasil à invasão americana no Iraque, o episódio do golpe de Honduras e o acordo tripartite entre Brasil, Turquia e Irã sobre o programa nuclear iraniano, que foi rejeitado pelo governo norte-americano. Outro tema polêmico foi a presença militar norte-americana na Colômbia, que foi um dos assuntos tratados na III reunião de Cúpula da Unasul. Na ocasião, o Presidente Lula demonstrou preocupação, e afirmou que "ainda havia Embaixadores (estadunidenses) que interferiam em eleições de outros países e que a IV Frota dos EUA preocupavam profundamente o Brasil", em função do pré-sal (BARRETO, 2012b, p.27). Segundo Pecequilo: "ao incrementar sua ação global, o Brasil passou a chocar-se mais com aquele país” (PECEQUILO, 2013, p.85).

Em relação à política externa do governo Lula para a América Latina, destaca-se ainda a Missão brasileira no Haiti e a criação da Comunidade de Estados Latino-Americanos e Caribenhos (CALC), em 2010. Conclui-se, portanto, que a política externa do presidente Lula para a América Latina teve como principal marca a busca de uma posição de liderança sul-americana. Esta estratégia se materializou na Unasul, que uniu o Mercosul à Comunidade Andina das Nações, e foi perseguido através de grandes investimentos brasileiros nos países vizinhos. A busca pela liderança regional está inserida dentro de uma estratégia mais ampla do presidente, de transformar o Brasil em uma potência global. 


\subsection{Discursos do presidente FHC nas Reuniões de Cúpula das Américas}

É dentro do contexto de frustração com o modelo neoliberal e com a configuração da ordem internacional que assume o Presidente Luiz Inácio Lula da Silva, em janeiro de 2003. Mas esta não é a única diferença em relação ao período em que FCH assumiu seu primeiro mandato. O crescimento da economia chinesa e a criação do acrônimo BRIC (lançado pelo economista Jim O’Neil em 2001) já indicavam que aos poucos o Brasil assumia um papel de maior relevância no sistema internacional, ao lado dos demais países emergentes. Como afirmou Celso Amorim, que ocupou o Ministério das Relações Exteriores durante todo o governo Lula, "neste mundo mais multipolar (...) o Brasil está disposto a ocupar um papel maior" (AMORIM, 2010, p. 216).

É a este novo cenário internacional que Lula faz referência no início de seu discurso na IV Reunião de Cúpula das Américas, que aconteceu em Mar del Plata, na Argentina, em 5 de novembro de 2005. Após relembrar os anos 1970, quando houve crescimento às custas de endividamento, os anos 1980, marcados pela crise da dívida externa, e finalmente aos anos 1990, definidos por ele com a "época do desmonte dos Estados Nacionais", o presidente afirma que a partir do século Xxi a América Latina vivia um novo período. Fazendo referência aos líderes latino-americanos ali presentes, ele afirma que este período é marcado pela eleição de presidentes que "na teoria clássica jamais poderia ter sido eleito Presidente da República” (PRESIDÊNCIA DA REPÚBLICA, 2005, p.2). A primeira coisa que chama a atenção é a referência do presidente especificamente ao espaço geográfico da América Latina, e o modo como o ele fala diretamente aos líderes latino-americanos. Além disso, Lula cria um ambiente de empatia com os demais presidentes da região, ao incluí-los todos dentro de um processo mais amplo de reorientação política.

Na sequência, Lula passa cerca de duas páginas expondo as conquistas de seus programas de governo, seja na geração de renda e empregos, na profissionalização dos trabalhadores ou no acesso à educação. A partir de números, o presidente demonstra os avanços sociais obtidos em sua gestão. A atitude contrasta com a do Presidente FHC, que em nenhum dos seus discursos fez referência aos projetos de seu governo no plano doméstico. Isso demonstra o interesse de Luiz Inácio Lula da Silva em apresentar-se como uma referência na região, em um discurso de tom quase eleitoral.

O discurso está em sintonia com a afirmação de Amorim de que o Brasil deveria ocupar um papel maior no cenário internacional, o que configura a principal modificação em relação ao período FHC. Luiz Inácio Lula da Silva exerceu uma "diplomacia empreendedora", que gerou um "sentimento de liderança, ao menos regional" (VIGEVANI e CEPALUNI, 2007, p.301). Como afirma Almeida (2010), Lula colocava a elevação do Brasil ao status de potência global no centro de sua diplomacia. Para seu Chanceler, o Ministro Celso Amorim, a diplomacia do governo Lula era "ativa e altiva” (BARNABÉ, 2010, p.42). 
Na sequência, Lula se volta para a questão da pobreza na América Latina e rejeita a busca de soluções estrangeiras para os problemas regionais, ao afirmar que "os nossos problemas são nossos" e criticando a subordinação de dirigentes latino-americanos às “doutrinas que pregavam facilidades nos anos 1980 e 1990”. (PRESIDÊNCIA DA REPÚBLICA, 2005, p.5). Mais uma vez, chama a atenção que o presidente se dirige aos seus colegas latino-americanos, e trata os representantes do Canadá e dos EUA quase como se eles não estivessem na reunião. E o recado que Lula passa para os demais presidentes é o de não se iludir com promessas estrangeiras, e sim buscar o desenvolvimento a partir de projetos próprios. Nas entrelinhas, está a resistência ao projeto da Alca. Na sequência, Lula segue se reportando aos seus colegas latino-americanos:

Quero dizer aos presidentes que eu me orgulho muito de ter vivido este momento na América Latina e na América do Sul. E que nós saímos de um Mercosul fracassado em 2002, para a construção não apenas do fortalecimento do Mercosul, mas da constituição da Comunidade Sul-Americana de Nações. Durante séculos, o Brasil ficou de costas para América do Sul, olhando para os Estados Unidos e para a União Européia, achando que tudo que era bom para os Estados Unidos era bom para o Brasil, ou tudo que era bom para a Europa era bom para o Brasil (PRESIDÊNCIA DA REPÚBLICA, 2005, p.5 e 6).

Ao mesmo tempo em que exalta o fortalecimento do Mercosul e a criação da Unasul, Lula lamenta o período em que o Brasil esteve mais próximo politicamente dos países desenvolvidos do que dos parceiros regionais. Mais uma vez, é marcante a estratégia do presidente de falar quase que exclusivamente para os colegas latino-americanos, utilizando-se de um espaço diplomático tradicionalmente pautado pelos Estados Unidos para defender projetos alternativos aos planos da grande potência.

Importante lembrar que a ascensão dos países emergentes foi acompanhada por uma tentativa de reordenação do sistema internacional, em um processo que teve o Brasil como um dos líderes. Neste contexto, a política externa do governo Lula buscou modificar este sistema a partir de parcerias com os demais países em desenvolvimento. Ao invés da "autonomia pela participação" descrita no governo FHC, Lula busca a "autonomia pela diversificação", caracterizada pela:

(...) adesão do país aos princípios e às normas internacionais por meio de alianças Sul-Sul, inclusive regionais, e de acordos com parceiros não tradicionais (China, Ásia-Pacífico, África, Europa Oriental, Oriente Médio, etc), pois acredita-se que eles reduzem as assimetrias nas relações externas com países mais poderosos e aumentam a capacidade negociadora nacional" (VIGEVANI e CEPALUNI, 2007, p.283). 
Para Cervo e Bueno (2011, p.526) o marco desta nova postura da política externa brasileira foi a Conferência da OMC em Cancun, em 2003. Desde então, "no entender da diplomacia brasileira, ou os emergentes tomam parte na confecção das regras, que se tornariam legítimas e justas, ou a produção das mesmas seria paralisada”. Foi nesta ocasião que surgiu o G20 comercial, com o objetivo principal de defender os interesses agrícolas dos países em desenvolvimento.

Na sequência do discurso, Lula comemora o que considera uma nova fase no relacionamento do Brasil com os vizinhos:

Durante muito tempo - a Bolívia está aqui - a Bolívia achava que o Brasil era um país imperialista do continente e que, portanto, os empresários bolivianos tinham medo dos empresários brasileiros e não tinham medo dos empresários de outros países. Durante muito tempo a Argentina e Brasil desconfiavam um do outro e assim por diante. Nós estamos conseguindo um feito inusitado, apesar das nossas diferenças, nós, hoje, estamos convencidos que não existe saída individual para nenhum país, não existe saída individual. Ou nós encontramos soluções conjuntas para financiar a nossa infra-estrutura, ou nós encontramos soluções conjuntas para facilitar o nosso comércio, ou nós não teremos solução (PRESIDÊNCIA DA REPÚBLICA, 2005, p.6).

Aqui fica nítido o desejo do presidente de descolar-se de um conceito do Brasil como um país imperialista na esfera regional. Vale lembrar que este era o maior receio do governo FHC, e que levava o presidente tucano a rejeitar uma postura de liderança. Lula tenta escapar deste dilema através do discurso da união entre os países e da busca por soluções conjuntas. Ao final do discurso, Lula se volta especificamente para o tema da Alca, e afirma que "o debate sobre comércio não pode ser uma coisa ideologizada":

Segundo, para o Brasil não faz sentido falar em livre comércio enquanto persistem os gigantescos subsídios da agricultura que desnivelam o campo de jogo. Terceiro, daí a prioridade da OMC, onde se pode tratar efetivamente dessa questão (PRESIDÊNCIA DA REPÚBLICA, 2005, p.6).

O recado é claro: o andamento das negociações da Alca está subordinado ao fim dos subsídios agrícolas dos países desenvolvidos. Importante notar que, ao contrário do período Fernando Henrique, em que as negociações da Alca estavam em seu auge, neste momento o projeto já se encontrava praticamente sepultado. Ou seja, tornava-se muito mais confortável para Lula emitir uma opinião tão incisiva quanto ao processo e integração. Ainda assim, Lula conclui se mostrando aberto ao diálogo, assim como fez Fernando Henrique ao final de seu discurso em 2001: 
Para o Mercosul e para o Brasil, eu acredito, (inaudível) nós temos negociado com outros países em desenvolvimento acordos em que tomamos plenamente em conta as assimetrias e sensibilidades dos países menos avançados. O mesmo princípio deve reger as negociações hemisféricas. Estamos dispostos a continuar essas discussões, mas não podemos fixar prazos artificiais que não serão cumpridos e que apenas causarão desgastes. Por isso, preferíamos avaliar a situação após Hong Kong, a luz do que ocorrer, sobretudo quando definirmos, claramente, a questão dos subsídios na reunião de Doha (PRESIDÊNCIA DA REPÚBLICA, 2005, p.7).

Lula usa o formato das relações mantidas pelo Brasil e o Mercosul como modelo daquilo que deve ser implementado nas negociações de um possível projeto de integração hemisférico. Trata-se de uma inversão de paradigmas: os países em desenvolvimento tornam-se exemplo para os países desenvolvidos. Também chama atenção a atitude de Lula de "dar as cartas" no processo de negociação, ao anunciar que só vai voltar a tratar da Alca após a nova reunião da OMC em Hong Kong.

Desta forma, o que mais chama a atenção no discurso de Lula é o fato de ele direcionar sua fala quase que exclusivamente para os líderes latino-americanos, o que reflete o aumento da intensidade no esforço pela integração regional durante o governo do petista. O presidente busca se apresentar como o porta-voz dos interesses da região, ao exaltar os avanços obtidos nos últimos anos e a necessidade de união para enfrentar os problemas sociais e de infraestrutura. Esta postura busca credenciar o Brasil a assumir a dianteira neste processo de integração sul-americano, que nesta época já estava institucionalizado na Comunidade Sul-Americana das Nações. Ao mesmo tempo em que busca a liderança regional, Lula tenta rejeitar a imagem do Brasil como um país imperialista. Por fim, o que mais chama a atenção no discurso de não são as críticas aos Estados Unidos, e sim a indiferença em relação ao país. Fica claro que o presidente não estava nesta reunião para mandar mensagens ao governo norte-americano, e sim para falar diretamente aos líderes latino-americanos, especialmente da América do Sul.

Já a V Reunião de Cúpula das Américas acontece na cidade de Porto de Espanha, em Trinidad e Tobago, no 18 de abril de 2009, em um contexto marcado pela crise financeira internacional, que levou à falência do banco Lehman Brothers no dia 15 de setembro de 2008. Segundo Ravenhill (2008), apesar dos efeitos da crise terem se espalhado rapidamente por todo o mundo (provocando em 2009 uma queda de $0,8 \%$ na produção mundial e de $12 \%$ no comércio global) os países desenvolvidos foram os mais atingidos. A incapacidade dos membros do G8 de administrarem sozinhos a crise provocou uma mudança importante na governança global, com a emergência do G20 como principal fórum de gerenciamento econômico internacional. Segundo Saraiva (2010), a fragmentação provocada pela crise de 2008, somada ao surgimento de novos players após os atentados de 11 de setembro, criaram o ambiente favorável à ascensão do Brasil no cenário internacional e para uma "abordagem revisionista do Brasil para a região" (SARAIVA, 2010, p.159, tradução nossa). 
A V Reunião de Cúpula também é a primeira a contar com a presença do recém-eleito presidente dos Estados Unidos, Barack Obama. Em seu discurso na primeira sessão plenária da reunião (nesta reunião Lula fala duas vezes), o presidente brasileiro começa por falar exatamente da crise econômica. Ele lembra da última reunião do G8, em Tóquio (julho de 2008), quando sugeriu que o tema da crise econômica fosse tratado não pelo G8, mas no âmbito das Nações Unidas, sugestão que não foi acatada. O presidente segue falando da necessidade de democratizar as relações internacionais:

É importante lembrar que, até poucos dias atrás, as decisões sobre a economia mundial eram tomadas, primeiro pelo G-7, depois pelo G-8, depois pelo G-8+5, e agora já são G-20, que não são 20, são 22. O que nós estamos percebendo? Que há uma evolução na participação dos países para decidir sobre uma crise que eu considero profunda, e uma crise que nasceu da irresponsabilidade do gerenciamento, pelos Estados, do sistema financeiro internacional (PRESIDÊNCIA DA REPÚBLICA, 2009a, p.1).

Este trecho inicial reflete com muito realismo o momento que o mundo vivia, de uma reordenação do sistema internacional a partir da crise financeira e da ascensão dos emergentes. Além de colocar em destaque este processo, Lula responsabiliza a falta de regulação financeira como a principal causadora da crise. Na sequência, o presidente fala do G20, e afirma: "Eu penso que quando eu, Cristina, Calderón, estamos no G-20, nós estamos falando em nome dos nossos companheiros da América Latina" (PRESIDÊNCIA DA REPÚBLICA, 2009a, p.1).

Aqui fica muito clara a intenção do presidente Lula de colocar o Brasil como um porta-voz dos interesses latino-americanos, assumindo desta forma uma posição de liderança regional. O presidente, no entanto, toma o cuidado de colocar o Brasil ao lado do México e da Argentina, a fim de evitar atritos com estes países e tornar mais humilde o discurso brasileiro. Não podemos esquecer que neste momento a ideia de uma liderança regional do Brasil não é meramente discursiva. O governo Lula promovera a intensificação do processo de internacionalização da economia brasileira. No início do seu segundo mandato, cerca de trinta empresas brasileiras haviam implementado em torno de 120 fábricas no exterior, tendo como principais destinos os Estados Unidos, Argentina, China e Bolívia (antes de Evo Morales). No mesmo período, o Brasil responde por quase cem bilhões de dólares em investimentos externos, liderados pela Petrobras, Vale do Rio Doce e Gerdau (CERVO, 2008, p.89).

Este processo de internacionalização conta com forte apoio do Estado, principalmente através do BNDES. Para muitos autores, esta intervenção do governo na economia é entendida como um retorno do modelo desenvolvimentista ${ }^{6}$. Segundo Lopreato (2014),

\footnotetext{
${ }^{6}$ Entende -se por desenvolvimentismo "a política formulada e/ou executada, de forma deliberada, por governos (nacionais ou subnacionais) para, através do crescimento da produção e da produtividade, sob
} 
esta reorientação da função do Estado fica mais clara a partir da substituição de Antônio Palocci por Guido Mantega na Secretaria da Fazenda, em 2006. O que se verifica neste período é o aumento do papel do Estado na promoção do desenvolvimento, através de investimentos em infraestrutura - com o Programa de Aceleração do Crescimento (PAC) - e de projetos como Política Industrial, Tecnológica e de Comércio Exterior (Pitce) e o Plano Brasil Maior. Além do cenário externo favorável, a expansão do consumo através da maior oferta de crédito e de programas de redistribuição de renda (como o Fome Zero) também foi peça chave para o crescimento da economia durante o governo Lula.

Ou seja, o governo Lula tirou proveito de um momento bastante positivo para as economias emergentes no sistema internacional, o que fortaleceu o protagonismo do Brasil na região. A seguir, Lula segue falando sobre as transformações pelas quais vinha passando o sistema internacional:

Acho que a reunião teve um avanço excepcional porque todo mundo está mais humilde. Já não há mais aquela arrogância do chamado mundo desenvolvido, dizendo o que nós tínhamos que fazer, porque a crise é de tal magnitude que ninguém sabe o que fazer. Ninguém tem mais a certeza absoluta. O FMI já não tem mais certeza absoluta, o Banco Mundial já não tem mais certeza absoluta. Nenhum governante tem mais certeza absoluta, porque a crise pegou todos nós (PRESIDÊNCIA DA REPÚBLICA, 2009a, p.2).

Desta forma, fica implícito durante todo o discurso a ideia de que já não são os países desenvolvidos quem dão as cartas do jogo no sistema internacional. O fim da "arrogância" a que se refere Lula se deve aos imensos prejuízos causados pela a crise econômica no primeiro mundo, ficando os países em desenvolvimento responsáveis por dar sustentação à economia internacional. $\mathrm{O}$ presidente brasileiro tenta tirar proveito deste contexto, como um momento estratégico para questionar a estrutura do sistema internacional e impulsionar o protagonismo brasileiro.

A análise se volta agora para o discurso do presidente Lula na segunda sessão plenária da $5^{\text {a }}$ Reunião de Cúpula das Américas. Mais uma vez, Lula começa seu discurso pelo tema da crise econômica, que segundo ele "teve sua origem no mundo desenvolvido, mas se espalhou por todos os continentes” (PRESIDÊNCIA DA REPÚBLICA, 2009b, p.1). Na sequência, reforça a tese de que a crise é reflexo de políticas fracassadas e de posturas intransigentes dos países desenvolvidos. Lula critica a política neoliberal dos anos 1980 e 1990, que segundo ele "desqualificava a política e a ação do Estado" e "ridicularizava a noção de soberania nacional” (PRESIDÊNCIA DA REPÚBLICA, 2009b, p.1 e 2). Lula

liderança do setor industrial, transformar a sociedade com vistas a alcançar fins desejáveis, destacadamente a superação de seus problemas econômicos e sociais, dentro dos marcos institucionais do sistema capitalista” (FONSECA, 2014, p.59). 
afirma, na sequência, que apesar das dificuldades os países da região conseguiram superar este período, e construíram projetos alternativos de desenvolvimento.

A região amadureceu coletivamente. Nossas políticas se guiam pelo respeito à diversidade, e estamos corrigindo assimetrias que prejudicam os parceiros menores. Sica, Caricom e Unasul, da mesma forma que o Mercosul, são exemplos de uma nova concepção de integração. Representam reais opções de governança regional que contribuem para a construção de um mundo multipolar, regido pelos princípios do multirateralismo. Esta cúpula demonstra que nossa região não admite fórmulas rígidas, pensamento único e imposições unilaterais. A integração das Américas supõe diálogo político e cooperação para o desenvolvimento (PRESIDÊNCIA DA REPÚBLICA, 2009b, p. 2).

Interessante notar que Lula não fala apenas em nome do Brasil, mas de toda a região. Isso fica claro quando utiliza o sujeito no plural (nós) para falar das medidas adotadas na busca pelo desenvolvimento. Destaca também os projetos de integração regional e a defesa de um mundo multipolar. Lula também dá um recado ao presidente norte-americano, ao afirmar que a região não irá mais tolerar ações unilaterais por parte dos EUA. Na sequência, o presidente rejeita de forma mais explícita qualquer tentativa de interferência na região, ao afirmar que "não hesitamos em enfrentar a violência e a criminalidade transnacional. O Conselho de Defesa da Unasul e o Conselho de Combate às Drogas buscarão soluções regionais para essas ameaças (PRESIDÊNCIA DA REPÚBLICA, 2009b, p. 2). Aqui, o objetivo do presidente é claramente o de rejeitar o Plano Colômbia e quaisquer outras formas de intervenção norte-americana sob a justificativa da segurança hemisférica.

Lula fala mais uma vez da segunda reunião de cúpula do G20, que havia ocorrido no dia 2 de abril em Londres. Lula reforça que "é, urgente reformar a arquitetura financeira mundial e os seus organismos"e que "na América Latina e no Caribe estamos fazendo nossa parte para vencer a crise, acelerando o ritmo de nossa integração em infraestrutura e fortalecendo as cooperações em políticas sociais" (PRESIDÊNCIA DA REPÚBLICA, 2009b, p. 3). Mais uma vez o presidente fala em nome do coletivo de países, e aponta o processo de integração regional como um dos caminhos para superar a crise.

Na sequência, Lula volta a tratar do tema das restrições ao comércio de produtos agrícolas, ao afirmar que a conclusão da Rodada de Doha "é fundamental". O presidente também fala da necessidade de aumentar os financiamentos aos países pobres: "o aumento do capital do BID, o fortalecimento da CAF e o lançamento definitivo do Banco do Sul ajudarão na retomada do crescimento e na geração de empregos (PRESIDÊNCIA DA REPÚBLICA, 2009 b, p. 3). Importante perceber que Lula cita três instituições financeiras regionais: o Banco Interamericano de Desenvolvimento, o Banco de Desenvolvimento da América Latina e o Banco do Sul, que seria lançado em 2014 sob a égide da Unasul. Esta é mais uma 
demonstração das mudanças que se operavam no sistema internacional, na qual os países em desenvolvimento buscavam criar suas próprias instituições de financiamento, deixando de depender do FMI ou do Banco Mundial. Ao se aproximar da parte final do discurso, Lula mais uma vez lamenta a ausência de Cuba no encontro e critica o bloqueio norte-americano à ilha. Mais uma vez, presidente conclui seu discurso em tom de conciliação:

O êxito desta cúpula depende do engajamento pleno de todos os países da região nessa empreitada. Nossos atos e gestos concretos demonstrarão que não há mais lugar em nosso continente para políticas de isolamento. Por meio da solidariedade, da inclusão e do respeito às diferenças poderemos estabelecer as bases para uma nova fase do desenvolvimento das Américas. Vamos tornar realidade o sonho de assegurar a todos os países acesso às oportunidades de crescimento econômico, à educação, à saúde, à segurança e à paz (PRESIDÊNCIA DA REPÚBLICA, 2009b, p. 5).

A mensagem que o presidente deixa ao final do discurso é no sentido de exaltar os projetos de integração, como se este fosse o único caminho para o desenvolvimento da região. Apesar de assumir um tom de líder deste processo, o presidente Lula procura suavizar o discurso com referências à solidariedade e ao respeito às diferenças. Ou seja, mais uma vez o presidente evitar adotar uma postura imperialista, ao mesmo tempo em que não abdica de uma posição de liderança para o Brasil.

O que mais chama a atenção na análise dos discursos do presidente Lula é o modo como ele assume a posição de porta-voz dos demais países latino-americanos. Além disso, o presidente se reporta quase que exclusivamente aos líderes destes países (e em especial da América do Sul), praticamente ignorando os representantes do Canadá e Estados Unidos. O discurso de Lula constrói, em certa medida, a imagem de dois personagens "nós" e "eles", onde "nós" são seus colegas latino-americanos e "eles" são os Estados Unidos, ao lado dos demais países desenvolvidos. Importante salientar que isso não torna o discurso do presidente agressivo: pelo contrário, o tom que predomina nos discursos é o de conciliação.

Outro ponto importante é a defesa da soberania nacional e a rejeição a qualquer tentativa de ingerência externa na região. Este elemento fica ainda mais saliente no $5^{\circ}$ encontro de cúpula, em função do novo papel assumido pelos países em desenvolvimento após a crise de 2008. Neste discurso, Lula deixa muito claro que o sistema internacional não é mais o mesmo, e que o país vai assumir uma postura mais ativa a partir do aumento da importância dos emergentes.

\section{Conclusão}

A análise dos discursos dos presidentes Fernando Henrique Cardoso e Luiz Inácio Lula da Silva nas reuniões de cúpula das Américas demonstra de forma clara as diferenças 
entre as políticas para o entorno regional implementadas pelos dois governos. Mais do que isso, demonstra que estas mudanças estão intimamente ligadas aos contextos em que se desenrolaram, e que não aconteceram de um momento para o outro. Ou seja, o que houve foi um processo de mudança, que teve início ao final do segundo mandato de FHC e ganhou força durante o governo Lula.

Ao analisar esta linha temporal, percebe-se que já houve uma mudança significativa no discurso de FHC entre sua primeira reunião (1998) e a segunda (2001). O primeiro discurso carrega um tom conciliatório e otimista, inclusive em relação à Alca. No segundo, Cardoso faz críticas a determinadas regras do comércio internacional e chega a dizer que a Alca pode ser “indesejável”. Também nesta segunda reunião FHC fortalece a defesa do Mercosul frente aos demais projetos de integração regional e demonstra sua insatisfação com a globalização e o liberalismo comercial.

Os discursos do presidente Lula reforçam o viés de autodeterminação e de defesa dos interesses nacionais, mas de forma diferente daquela adotada por FHC. No primeiro discurso, (2005) ao invés de criticar diretamente os EUA, o presidente opta por praticamente ignorar a presença do presidente norte-americano. Seu discurso é todo voltado para os líderes latino-americanos, tanto no sentido de defender os processos de integração regionais como de buscar soluções nacionais para os problemas dos países. No segundo discurso (2009), o que predomina é a defesa de uma nova ordem global diante da reorganização do sistema internacional após a crise de 2008. Mais uma vez, Lula se coloca como porta-voz dos países da região. É este o principal contraste entre os discursos dos dois presidentes: enquanto FHC evita posicionar o Brasil como líder regional, Lula o faz continuamente, ainda que tomando o cuidado de não parecer imperialista.

Os dois discursos, no entanto, também têm elementos em comum: ambos fazem a defesa dos processos de integração sub-regionais. FHC defende o Mercosul como um elemento prioritário e inegociável da política externa brasileira. Importante lembrar que adotar esta postura era de extrema importância diante da pressão exercida pelos EUA nas negociações da Alca que ocorriam naquele período. Lula também coloca a integração regional como prioridade em seus discursos, mas o foco principal deixa de ser o Mercosul e passa a ser a Unasul e o continente sul-americano como um todo. Importante lembrar que este movimento de sul-americanização da política externa brasileira começou ainda no governo FHC, quando ele convocou a primeira reunião de cúpula da América do Sul.

Os dois presidentes também tiveram nos investimentos em infraestrutura uma das principais formas de promover a integração regional. No caso do governo Lula, esta estratégia foi fortalecida pelo bom momento da economia brasileira em função do boom das commmodities. Além disso, o governo do PT apostou em uma estratégia neodesenvolvimentista, que impulsionou a internacionalização de empresas brasileiras. Internacionalização esta que já existia no governo FHC, mas com uma diferença importante. Enquanto 
no período Cardoso o principal movimento era da entrada de empresas estrangeiras no país (principalmente através das privatizações), no período Lula este movimento começa a se inverter, e as empresas brasileiras passam a investir em outros países.

Ambos os presidentes também defenderam a busca de soluções pacíficas para os conflitos do continente, com a prevalência do diálogo, e repudiaram a adoção de medidas unilaterais por parte dos EUA. Na relação com o governo norte-americano, percebe-se que os discursos de Cardoso oscilaram entre dois extremos: na primeira reunião o tom era amigável e otimista; na segunda, o presidente expôs sua frustração com o liberalismo econômico e mencionou diversos pontos de atrito com o governo americano. Lula, por sua vez, adotou um tom mais ameno em relação aos Estados Unidos em ambos os discursos: no primeiro o presidente praticamente ignorou o governo norte-americano; enquanto no segundo a figura dos EUA ficou diluída nas referências às transformações no sistema internacional.

Ou seja, a análise dos discursos dos presidentes FHC e Lula nas reuniões de cúpula das Américas permite concluir que, de fato, ambos priorizaram os processos de integração regional. Cada governo, no entanto, teve uma ênfase diferente: FHC no Mercosul e Lula na Unasul. Cada presidente também assumiu uma postura diferente na relação com o continente latino-americano. Fernando Henrique evitou assumir uma posição de liderança regional, enquanto Lula se colocou claramente como um porta-voz e um líder da região. Ambos os presidentes apostaram nos investimentos em infraestrutura como motores do processo de integração e do desenvolvimento regional, e rechaçaram interferências externas nos assuntos regionais.

Antes de concluir, vale destacar uma variável que, apesar de não ser o foco deste trabalho, está sempre presente quando o assunto é análise de discurso: a performance de cada presidente. FHC e Lula tem trajetórias políticas muito diferentes, o que se reflete no seu modo de se expressar. FHC, que gozava de prestígio internacional pela carreira acadêmica como cientista político e sociólogo, possui um discurso mais formal e diplomático. Lula, por sua vez, surgiu na política como um líder sindical, acostumado a discursar para trabalhadores do setor metalúrgico. O seu discurso, por consequência, carrega um tom mais político e incisivo. Destaca-se ainda a personalidade carismática do presidente Lula, que lhe rendeu fama internacional. Estas características, evidentemente, não alteram a mensagem de seus discursos, mas certamente fornecem mais elementos para a compreensão dos aspectos que diferenciam a política externa de cada presidente.

\section{BIBLIOGRAFIA}

ALMEIDA, Paulo R. de - Nunca visto antes no Brasil: a grande diplomacia de Lula. Rev. Bras. Polit. Int., [Em linha]. v. 53, n.02 (2010), [Consult. 9 nov. 2014]. Disponível em WWW: <URL:http://www.scielo.br/pdf/rbpi/v53n2/09.pdf>. ISSN 1983-3121 
AMORIM. Celso. Brazil Foreign Policy under President Lula (2003-2010): an overview. Rev. Bras. Polít. Int., Brasília: Instituto Brasileiro de Relações Internacionais. ISSN 0034-7329. v. 53, número especial (2010), p. 214-240.

BANCO CENTRAL DO BRASIL. [Consult. 9 abr. 2016]. Disponível em: WWW: $<$ URL: $<$ http://www.bcb.gov.br/glossario.asp?Definicao=72\&idioma=P\&idpai= GLOSSARIO>

BARNABÉ, Israel Roberto. O Itamaraty e a Diplomacia Presidencial nos governos FHC e Lula. Revista de Estudos Internacionais (REI), João Pessoa: Universidade Estadual da Paraíba. ISSN: 2236-4811.vol. 1, num. 2 (2010), p. 29 - 45.

BARRETO, Fernando de Mello. - A política externa após a redemocratização - Tomo I - 1985 - 2002. Brasília: FUNAG, 2012a, 745 p. ISBN: 978-85-7631-363-2

- A política externa após a redemocratização. - Tomo II - 2003 - 2010. Brasília: FUNAG, 2012b, 668 p. ISBN: 978-85-7631-382-3

BERRINGER, Tatiana. - Bloco no Poder e política externa nos governos FHC e Lula. Campinas: Instituto de Filosofia e Ciências Humanas, Universidade Estadual de Campinas. 2014. Tese de Doutorado em Ciência Política.

CERVO, Amado; BUENO, Clodoaldo. História da Política Exterior do Brasil. ${ }^{\mathrm{a}}$ Edição revista e ampliada. Brasília: Editora Universidade de Brasília, 2011. 595p. ISBN 85-230-0661-3

CERVO, Amado. Inserção Internacional: formação dos conceitos brasileiros. São Paulo: Saraiva, 2008. 297p. ISBN: 9788502065703

COUTO, Leandro de Freitas. Política externa brasileira para a América do Sul: as diferenças entre Cardoso e Lula, Civitas - Revista de Ciências Sociais, Porto Alegre: Programa de Pós-Graduação em Ciências Sociais da Faculdade de Filosofia e Ciências Humanas da PUCRS. e-ISSN: 1984-7289. V. 10, n. 1 (2010), p.23-44.

FONSECA, Pedro Cezar Dutra. - Desenvolvimentismo: a construção do conceito. In: CALIXTRE, André Bojikian; BIANCARELLI, André Martins; CINTRA, Marco Antonio Macedo. Presente e Futuro do desenvolvimento brasileiro. Brasília: IPEA, 2014. p. 29-78. ISBN: 978-85-7811-214-1

GRATIUS, Susanne. O Brasil nas Américas: Potência regional pacificadora? FRIDE. Relatório 35 (2007) [Consult. 22 mai. 2016]. Disponível em WWW: <URL: http://fride. org/descarga/WP35_BraAmer_POR_abr07.pdf>.

HARVEY, David. - O novo imperialismo. $2^{\text {a }}$ Ed. São Paulo: Loyola, 2005, 201p. ISBN13: 9788515029716

HOLAND. Carla A.R. - A Política Externa do Governo Lula (2003-2010) para o Oriente Médio: Precedentes, Avanços e Retomadas. Porto Alegre: Faculdade de Ciências Econômicas da Universidade Federal do Rio Grande do Sul. 2013. Dissertação de Mestrado em Estudos Estratégicos Internacionais.

LOPREATO, Francisco Luiz C. - Aspectos da atuação estatal de FHC a Dilma. 
In: CALIXTRE, André Bojikian; BIANCARELLI, André Martins; CINTRA, Marco Antonio Macedo - Presente e Futuro do desenvolvimento brasileiro. Brasília, DF: IPEA. 2014. ISBN: 978-85-7811-214-1. p.227-260.

MARTINS, Fernanda Tondolo. Política Externa no governo do Presidente Fernando Henrique Cardoso: A articulação regional e a integração sul-americana (1995-2002). Porto Alegre: Programa de Pós-graduação em História da Universidade Federal do Rio Grande do Sul, 2006. Dissertação de Mestrado em História

MILNER, Helen V. - The Political Economy of International Trade. Annual Review of Political Science. Palo Alto: Annual Reviews. ISSN 1545-1577 v.02 (1999), p. 91 - 114.

MINISTÉRIO DE RELACIONES EXTERIORES. Memoria de la II Cumbre de las Américas: Chile 18 y 19 de abril de 1998. Santiago: República do Chile, 1998. 619 p.

ORGANIZAÇÃO DOS ESTADOS AMERICANOS - Cumbre de las Américas. [Consult. 19 mai. 1016]. Disponível em < http://www.summit-americas.org/defaults.htm>.

MUNIER, Isabel; MEDEIROS, Marcelo de Almeida. Construindo a América do Sul: Identidades e Interesses na Formação Discursiva da Unasul. DADOS - Revista de Ciências Sociais, Rio de Janeiro: Instituto de Estudos Sociais e Políticos (IESP). ISSN 16784588. V. 56, n. 3 (2013), p.673 - 712.

PECEQUILO, Cristina - Brasil e Estados Unidos: Um enfoque contemporâneo das relações bilaterais. In: LESSA, Antônio Carlos; e OLIVEIRA, Henrique Altemani de (Org) - Parcerias estratégicas do Brasil: os significados e as experiências tradicionais. Belo Horizonte: Fino Traço Editora, 2013. ISBN: 978-85-8054-127-4. p.69-90.

- Política Internacional. $2^{\mathrm{a}}$ Ed. Atualizada. Brasília: Fundação Alexandre Gusmão, 2012. 398p. ISBN: 978-85-7631-404-2

-. A Política Externa do Brasil no Século XXI: Os Eixos Combinados de Cooperação Horizontal e Vertical. Revista Brasileira de Política Internacional [Em linha]. V. 51, n. 02 (2008). [Consult. 3 nov. 2014]. Disponível em: <http://www.scielo.br/pdf/rbpi/v51n2/ v51n2a09.pdf>. ISSN 1983-3121.

PRESIDÊNCIA DA REPÚBLICA. Discurso do Presidente da República, Luiz Inácio Lula da Silva, na Primeira Sessão Plenária da $5^{\text {a }}$ Cúpula das Américas: Porto de Espanha - Trinidad e Tobago, 18 de abril de 2009. Brasília: BRASIL. [Consult. 19 mai. 2016]. Disponível em WWW: <URL: http://www.biblioteca.presidencia.gov.br/presidencia/ ex-presidentes/luiz-inacio-lula-da-silva/discursos/2o-mandato/2009/18-04-2009-discurso-do-presidente-da-republica-luiz-inacio-lula-da-silva-na-primeira-sessao-plenaria-da-5a-cupula-das-americas/view>

—. Discurso do Presidente da República, Luiz Inácio Lula da Silva, na Segunda Sessão Plenária da $5^{\mathrm{a}}$ Cúpula das Américas: Porto de Espanha - Trinidad e Tobago, 18 de abril de 2009 Brasília: BRASIL. [Consult. 19 mai. 2016]. Disponível em WWW: <URL: http://www.biblioteca.presidencia.gov.br/presidencia/ex-presidentes/ luiz-inacio-lula-da-silva/discursos/2o-mandato/2009/18-04-2009-discurso-do-presidente-da-republica-luiz-inacio-lula-da-silva-na-segunda-sessao-plenaria-da-5a-cupula-das-americas/view> 
—. Intervenção do Presidente da República, Luiz Inácio Lula da Silva, na Segunda Sessão da IV Cúpula das Américas: Mar del Plata - Argentina, 05 de novembro de 2005. Brasília: BRASIL. [Consult. 19 mai. 2016]. Disponível em WWW: <URL: http:// www.biblioteca.presidencia.gov.br/presidencia/ex-presidentes/luiz-inacio-lula-da-silva/ discursos/1o-mandato/2005/05-11-2005-intervencao-do-presidente-da-republica-luiz-inacio-lula-da-silva-na-segunda-sessao-da-iv-cupula-das-americas/view>

—. Discurso na abertura da III Reunião de Cúpula das Américas: Quebec, Canadá, 20 de abril de 2001. Brasília: BRASIL. [Consult. 19 mai. 2016]. Disponível em: WWW: $<$ URL:http://www.biblioteca.presidencia.gov.br/presidencia/ex-presidentes/fernando-henrique-cardoso/discursos/2o-mandato/2001/35.pdf/view>

—. Pronunciamento do Presidente da República - Posse no Congresso Nacional: Brasília - DF, 01 de janeiro de 1999. [Em linha]. Brasília: BRASIL. [Consult. 19 mai. 2016] Disponível em: WWW: <URL:http://www.biblioteca.presidencia.gov.br/presidencia/ex-presidentes/fernando-henrique-cardoso/discursos/2o-mandato/1999-1/01. $\mathrm{pdf} / \mathrm{view}>$.

RAVENHILL, John. The study of global political economy. Oxford: Oxford University Press, 2008, 570p. ISBN: 9780199666010

SALAMA, Pierre. - Uma globalização comercial acompanhada de uma redistribuição dos mapas. Ensaios FEE. Porto Alegre: Fundação de Economia e Estatística. ISSN 01011723. v. 33, n. 02 (2012), p. 307-331.

SANTOS, LUIS Cláudio Villafañe G. A América do Sul no discurso diplomático brasileiro. Brasília: FUNAG, 2014. 248p. ISBN 978-85-7631-525-4

SARAIVA, Miriam Gomes. Brazilian Foreign policy towards South America during the Lula Administration: caught between South America and Mercosur. Rev. Bras. Polit. Int. Brasília: Instituto Brasileiro de Relações Internacionais. ISSN 0034-7329. n.53, ed. Especial (2010), 151-168.

SILVA, André L. R. da. - Do otimismo liberal à globalização assimétrica: a política externa do governo Fernando Henrique Cardoso (1995-2002). Porto Alegre: Programa de Pós-graduação em Ciência Política da Universidade Federal do Rio Grande do Sul. 2008. Tese de Doutorado em Ciência Política.

-. O Brasil diante da globalização: a política externa do governo Fernando Henrique Cardoso (1995-2002). Belo Horizonte: Carta Internacional. ISSN: 1413-0904. v.07, n.01 (2012). p. 20-34.

SIMÃO, A. R. F. - A Diplomacia Presidencial e o Processo de Inserção Internacional do Brasil: Um Estudo da Política Externa do Governo de Fernando Henrique Cardoso. In: XV Simpósio Nacional de História. Fortaleza, Editora, 2009.

VIGEVANI, Tulio; CEPALUNI, Gabriel. - A Política Externa de Lula da Silva: A Estratégia da Autonomia pela Diversificação. Contexto Internacional. Rio de Janeiro: Instituto de Relações Internacionais da PUC-Rio. ISSN 0102-8529 v.29, n 02 (2007), p. 273-335. 
VIGEVANI, Tullo; OLIVEIRA, Marcelo F. de; CINTRA, Rodrigo. Política externa no período FHC: a busca de autonomia pela integração. Tempo Social. São Paulo: USP. ISSN: 1809-4554. v. 15, n. 2 (2003), p.31-61.

Williamson, John. - What Should the World Bank Think About the Washington Consensus? World Bank Research Observer. Washington, DC: The International Bank for Reconstruction and Development. ISSN 0257-3032 . 15, N. 2 (2000), p. 251-264.

Artigo Recebido a 29 de abril de 2016 | Aceite a 30 de junho de 2016 